\title{
A Transient Chaotic Associative Memory Model with Temporary Stay Function
}

\author{
Masanao ObayashiＭember (Yamaguchi University, m.obayas@yamaguchi-u.ac.jp) \\ Kenichiro Narita Non-member (Yamaguchi University, narita@nn.csse.yamaguchi-u.ac.jp) \\ Kunikazu Kobayashi Non-member (Yamaguchi University, koba@yamaguchi-u.ac.jp) \\ Takashi KuremotoＮon-member (Yamaguchi University,wu@yamaguchi-u.ac.jp)
}

Keywords : transient chaos, associative memory, temporary stay function

When chaotic characteristic is given to neurons which constitute the associative memory model, model operates to change its state dynamically by the fact that chaotic transition is repeated. But because operation is chaotic, it has the fault that whether presence of target pattern retrieval on display is or not is difficult. This is because that each neuron does not stay in a pattern retrieval state. On the one hand, Lee oscillator based auto-associative network, which transits from chaos state to stable state (non chaos) transiently, has the characteristic that the retrieval speed is fast and memory capacity is large, but chaotic dynamics is not seen after model converges to stable state.

In this research, a memory model with above both networks merits is proposed. Our proposed neuron is as follows,

$$
\begin{aligned}
& z(t+1)=f\left(R B F\left(\mu, \sigma^{2}\right) \cdot \operatorname{chaos}(t)+\left(1-R B F\left(\mu, \sigma^{2}\right)\right) \cdot z(t)+I_{\text {out }}(t)\right) \\
& R B F\left(\mu, \sigma^{2}\right)=e^{-\frac{(x-\mu)^{2}}{\sigma^{2}}} \\
& f(x)=\tanh (\varepsilon \cdot x)
\end{aligned}
$$

The proposed neuron with Eq.(1) (3) has the dynamics which is similar to Lee oscillator. The Hopfield Network(HN) type memory model which consists of the proposed neurons reached having the character which is similar to that of $\mathrm{HN}$ which consists of Lee oscillators, but dynamic transition of the network state from an attractor to the other ones is not seen after retrieval.

Therefore, a new function, which makes networks staying during a certain time at a retrieval pattern, this is not possible for the conventional chaotic neural networks, is added to above proposed neurons, by introducing the reduction of external input shown in Eq.(4) (10).

$$
\begin{aligned}
& I_{\text {out }}(t)=S_{\text {rate }} \cdot I(t) \\
& S_{\text {rate }}=\beta \quad \text { if. } B(t-1)<0 \& B(t)>0 \\
& S_{\text {rate }}=A(t) \quad \text { Otherwise. } \\
& A(t)=\frac{4.0}{\max _{t}(I)+\min _{t}(I)} \\
& B(t)=k_{r} \cdot B(t-1)-\alpha \cdot x(\Delta I(t))+a \\
& B(t)=B_{\max } \quad \text { if } . B(t)>B_{\max } \\
& \Delta I(t)=|I(t)-I(t-1)| \\
& x(\Delta I(t))=2 \quad \text { if } . \Delta I(t-1), \Delta I(t)=0 \& B(t-1)>0 \\
& x(\Delta I(t))=0 \quad \text { Otherwise. }
\end{aligned}
$$

Simulation is carried out for the confirmation of the above ability, consisting the proposed neuron based associative memory model. Fig. 1 shows the stored patterns. Fig. 2 shows change of the network energy function value according to progression of the steps. We can see some constant value line named (a) (1). This means that the network recollects a pattern and stays there for a while, then re-chaos operation starts. The retrieval patterns at each symbol(a) (1) are shown in Fig.3. In Fig.3, the proposed model recollects the stored patterns precisely. Other characteristics is, not described in this abstract (refer to main paper), that the capacity of the stored patterns of the proposed model is higher than chaotic neural network by Aihara et.al..

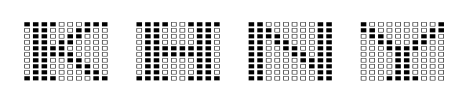

Fig. 1. Stored patterns

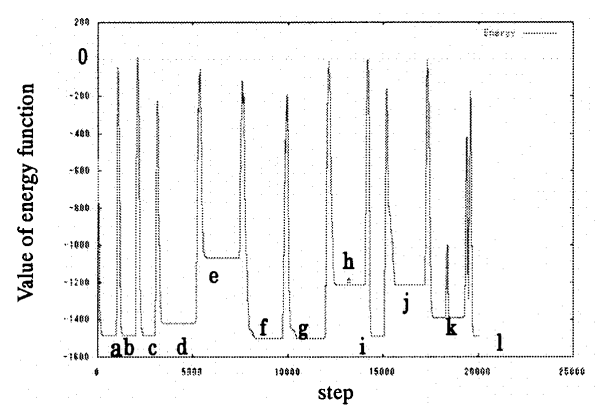

Fig. 2. Change of the energy function value of the proposed model

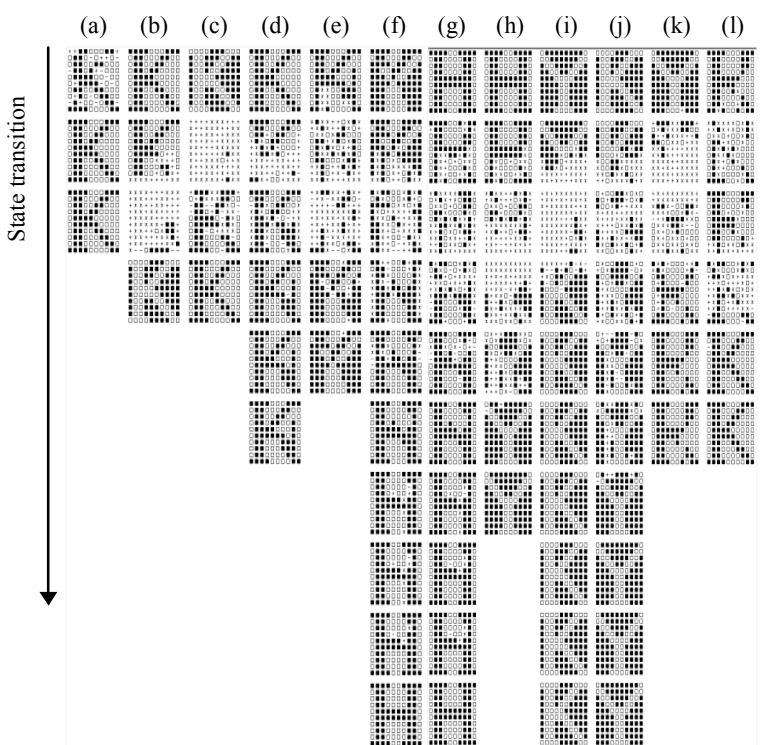

Fig. 3. State transition of the proposed model for each period in Fig. 2 


\title{
一時的滞留機能を持つ過渡的カオス連想記憶モデル
}

正員 大林 正直* 非会員 成田顕一郎*
非会員 小林 邦和*
非会員 呉本 克*

\author{
A Transient Chaotic Associative Memory Model with Temporary Stay Function \\ Masanao Obayashi*, Member, Kenichiro Narita*, Non-member, \\ Kunikazu Kobayashi*, Non-member, Takashi Kuremoto*, Non-member
}

\begin{abstract}
When chaotic dynamics is given to the neurons that compose the associative memory model, it searches for stored patterns in a pattern space chaotically. However, it has the fault that the judgment for whether the stored pattern is recollected or not is difficult because its behavior is always chaotic. As all dynamics of the chaotic neurons are chaotic, chaotic transition is repeated. One side, transient-chaotic associative network (TCAN) Lee proposed changes from the state of chaos to the state of stability (non-chaos) transiently. Additionally, it has the fast recollection speed, and has the characteristic, high memory capacity. However, the states of TCAN do not change chaotically. Based on these results, this paper proposes a transient chaotic associative memory model with temporary stay function (TCAMMwithTSF) which has two abilities: one is the fast speed at the states of the model converge to a stored pattern, like TCAN, the other is the ability that it searches the stored pattern in a pattern space chaotically, like chaotic neural networks. Finally, it is verified that what character TCAMMwithTSF has and its usefulness through simulation study.
\end{abstract}

キーワード : 過渡的カオス, 連想記憶, 一時的滞留機能

Keywords : transient chaos, associative memory, temporary stay function

\section{1. まえがき}

生体の嗅覚系神経回路網にカオスの存在が示唆される データが発表され(1), また，人閒の脳が持つ高度な情報処理 機能にカオスが重要な役割をはたしているのではないかと いう研究もなされている(2)。合原らは, ニューロンにおいて もカオス現象が観測されることをヤリイカ巨大軸索を用い た電気生理学的実験によって明らかにし(3), カオスダイナ ミックスを有するカオスニューロンモデルとしてモデル化 し，これを構成要素とする相互結合型カオスニューラルネッ トワーク (Chaotic Neural Network : CNN) を提案している(4)。 この CNN を用いた自己想起型連想記憶モデルでは，ネット ワークに記憶された複数のパターンを動的に想起可能なこ とが知られている (カオス的遍歴)。このカオス的遍歴は従 来の Hopfield Network $(\mathrm{HN})^{(5)}$ の自己想起型連想記憶モデル にはない特徴で, カオスニューロンの不応性の影響により, 局所安定点から状態が突発的に変化することにより発生す る(6)。しかしながら，この CNNを用いた連想記憶モデルで

\footnotetext{
* 山口大学大学院理工学研究科

干755-8611 山口県宇部市常盤台 2-16-1

Graduate School of Science and Engineering Yamaguchi University

2-16-1 Ube city Tokiwadai, Yamaguchi 755-8611
}

はカオス的遍歴機能による動的なパターン想起がなされる もののパターン想起状態でカオス的遍歴を一時的に停止す る制御機能は有していない。顔画像, 風景画像等を連想記 憶モデルへ取り込み, 想起されたパターンを目視により確 認する場合, 想起状態で一定時間停止状態を保つことは有 用かつ必要な機能と考えられる。

一方, 生物に存在すると考えられているリズミックなパ ターンを生成する神経系をモデル化した神経振動子があ り,その一つに Lee Oscillator がある。Lee は Lee Oscillator を 提案すると共に, これを構成要素とする Hopfield 型連想記 憶モデルである Transient-Chaotic Autoassociative Network (TCAN) を提案している(7)。このモデルでは, シグモイド関 数を利用した, 興奮, 抑制, 入力の 3 つのニューロンで一 個のニューロン (oscillator) を構成し, その出力として過度 的カオスを発生させ, 記銘パターンへ収束しやすい状況を 作り出している。この過渡的なカオス機能により, 状態空 間を正確に素早く探索し，記銘パターンに収束するという 特性を持っている反面, 記銘パターン間をカオス的に遷移 するようなカオス的遍歴機能を有していない。

本研究では, CNN のカオス的遍歴機能, 及びパターン想 起後一時的な滞留機能を持つ過渡的カオス連想記憶モデル 
(Transient Chaotic Associative Memory Model with Temporary Stay Function：TCAMMwithTSF) を提案する。

ネットワーク状態のカオス, 非カオスの制御を実現する 方法として, カオスニューロンのパラメータを調整する方 法 ${ }^{(8)}$ が既に提案されているが, 本研究ではパラメータの調整 によらず, 内部状態の変化のみで自動的にカオス, 非カオ ス間の遷移を実現する。

提案法ではニューロンを合原らのカオスニューロンと動 径基底関数 (Radial Basis Function : RBF) を組み合わせて, 内部状態をつくり，ニューロン出力として過度的カオスを 得ている。この RBF の広がりを調整することで，入力に対 するニューロン出力のカオス領域が設定しやすいという特 徵をもっている。また，Lee の TCAN が，ある記銘パター ン出力状態で停止するのに対し, TCAMMwithTSF では, 記 銘パターンを出力している状態を一時的に継続し, 縮小 ニューロンの作用により，ネットワークが非カオス状態か らカオス状態へ自動的に遷移する，カオス的遍歴を実現し ている。

本論文の構成は以下の通りである。第 2 章では, CNN と その特性について, 第 3 章では提案ニューロンの構成と過 渡的カオス連想記憶モデル (TCAMM) が持つ性質につい て,第 4 章では一時的滞留機能を持つ TCAMM (TCAMMwith TSF) について，第 5 章では提案した TCAMMwithTSF に関 する計算機シミュレーションにより，その有効性を確認す る。そして，第 6 章はまとめである。

\section{2. カオスニューラルネットとその特性}

合原らは従来のニューロンモデルに生物のニューロンが 示すカオス応答を取り入れ，カオスニューロンとしてモデ ル化し，これを要素とするネットワーク $(\mathrm{CNN})^{(4)}$ を構成し た。CNN は次式で表される。

$$
\begin{aligned}
& x_{i}^{c}(t+1)=f\left(y_{i}^{c}(t+1)+z_{i}^{c}(t+1)\right) \\
& y_{i}^{c}(t+1)=k_{r} y_{i}^{c}(t)-\alpha x_{i}^{c}(t)+a_{i} \\
& z_{i}^{c}(t+1)=k_{f} z_{i}^{c}(t)+I_{\text {out }}(t) \quad(i=1, \cdots, n) \\
& f(x)=\tanh (\varepsilon \cdot x)
\end{aligned}
$$

ここで, $x_{i}^{c}(t)$ は時刻 $t$ での $i$ 番目のカオスニューロンの出 力值, $n$ はニューロン数, $y_{i}^{c}(t)$ は $i$ 番目ニューロンにおけ る不応性に関する内部状態項, $z_{i}^{c}(t)$ は $i$ 番目ニューロンに おける相互作用に関する内部状態項， $a_{i}$ は $i$ 番目ニューロン における外部入力と閾值の複合項， $k_{r}, k_{f}$ はそれぞれ，不 忘性，フィードバック項に関する時間減衰定数， $\alpha$ は定数 パラメータ, $f(\cdot)$ は活性化関数, $\varepsilon$ は活性化関数の傾きに関 するパラメータである。 $n=1$ の場合，即ち，カオスニュー ロンへの種々の定数外部入力 $\left(I_{\text {out }}=\right.$ External Stimulus (I)) に対するニューロンの出力を Fig.1 に示す。Fig.1 は, 各変数 $x, y, z$ の初期值を 0 とし，初期值の影響がなくなるように， 更新を十分繰り返した後, 最後の 10 ステップのニューロン

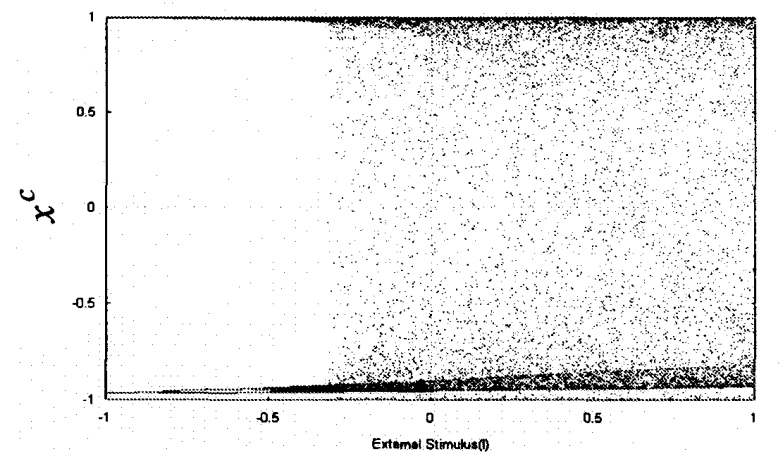

Fig. 1. Dynamics of a chaotic neuron

Table 1. Parameter set used in the CNN

\begin{tabular}{llc}
\hline \hline Symbol & \multicolumn{1}{c}{ Quantity } & values \\
\hline$\varepsilon$ & slope of sigmoid function & 5.0 \\
$\alpha$ & scaling parameter & 10.0 \\
$k_{f}$ & decay parameter for internal state & 0.3 \\
$k_{r}$ & $\begin{array}{l}\text { decay parameter for mutual interaction state } \\
a_{i}\end{array}$ & $\begin{array}{l}\text { composite term of external input and } \\
\text { threshold of i-th neuron magnetization }\end{array}$ \\
\hline \hline
\end{tabular}

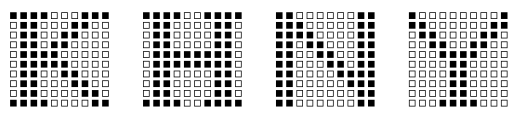

(a) Stored patterns

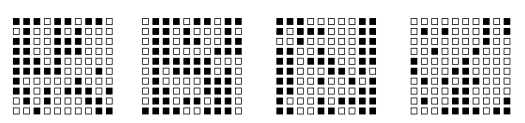

(b) Input patterns with noise (rate of noise/signal $=0.2$ )

Fig. 2. Stored patterns and input patterns

出力をプロットしたものである。尚, 定数外部入力は $10^{-4}$ 刻みで与えた。Fig.1 より外部入力の広い範囲でカオス状態 であることがわかる。

\section{CNN の特性}

$\mathrm{CNN}$ を用いた連想記憶シミュレーションを行う場合, $i$ 番 目ニューロンと $j$ 番目ニューロンとのニューロン間の結合 荷重 $\omega_{i j}$ を用いて(3)式の $I_{\text {out }}$ は次式で表わされる。

$$
\begin{gathered}
I_{\text {out }}(t)=\sum_{j=1}^{n} \omega_{i j} x_{j}^{c}(t) \\
\omega_{i j}=\frac{1}{N_{p}} \cdot \sum_{p=1}^{N_{p}} x_{i}^{p} \cdot x_{j}^{p}
\end{gathered}
$$

ここで $N_{p}$ は記憶パターン数, $x_{i}^{p}$ はネットワークに記銘され ている $i$ 番目ニューロンの $p$ 番目記銘パターンである。

\section{$\mathrm{CNN}$ 特性確認シミュレーション}

Table 1 にシミュレーションに用いたパラメータの值を, Fig.2 はニューロン数 $n=100$ の場合の記銘パターン(a)とそ れぞれに $20 \%$ のノイズを含んだ初期パターンの例(b)を示 


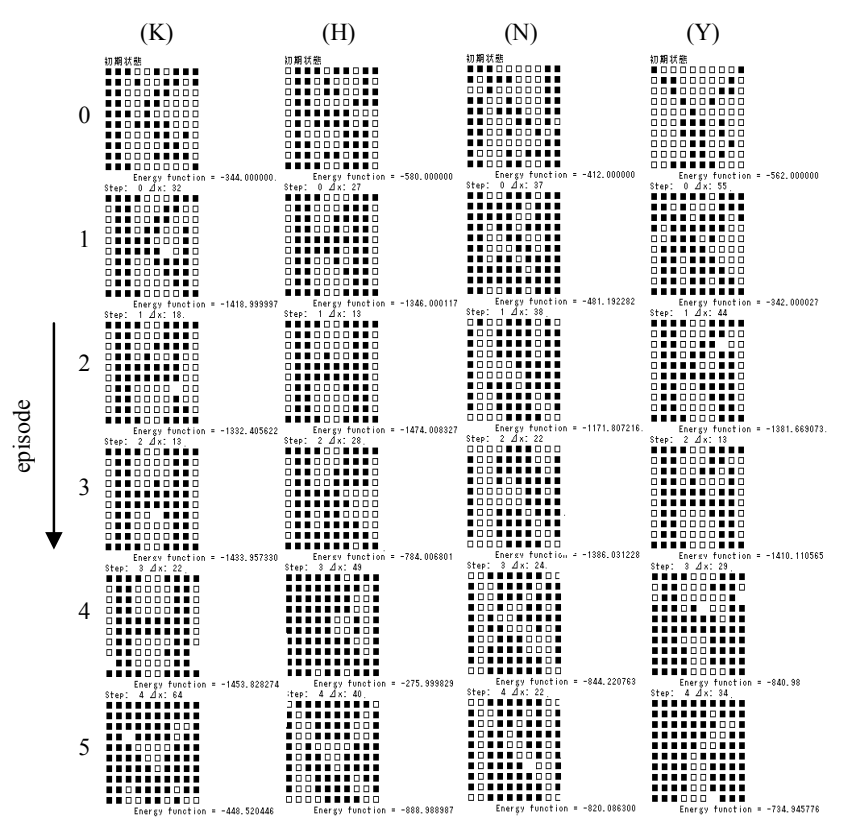

Fig. 3. Change of retrieval patterns at first 5 episodes

す。シミュレーションでは $4\left(=N_{p}\right)$ 個のパターン (Fig.2(a)) を記銘し，4 個のうち一つの記銘パターンに 20\%のノイズ パターンを初期パターン（Fig.2(b)参照）としてネットワー クを動作させた。初期状態から 1 ステップでネットワーク 内のいずれか 1 個のニューロンの状態が更新されるとし， 全てのニューロンが更新されたサイクルを 1 エピソードと 定義する（ネットワークを動作させる場合，全ニューロン を同時に更新する同期式とニューロンを 1 個ずつ更新する 非同期式があるが，ここでは，Hopfield モデルで仮定されて いる非同期式を採用した)。Fig.3に K,H,N,Y それぞれに $20 \%$ のノイズを付加したパターンを初期状態としてそれぞれ個 別にネットワークを動作させ，それぞれの初期パターン（列 表示）から最初の 5 エピソード（行表示）の状態を示す。 CNN においては，いずれの場合においても，複数のエピソー ド経過後, 初期パターンに依存せず複数の記銘パターンと 類似パターンにはなるものの，両者は正確に一致していな い。Fig.4 はそのときのネットワークのステップ毎のエネル ギ一関数值の変化の一例である。これより，CNN の場合， 想起パターンと記銘パターンの一致・不一致に関係なく, 非周期的な遷移をしていることが分かる。また，エネルギー 関数の定義は下記としている。

$$
E=-\frac{1}{2} \sum_{i=1}^{n} \sum_{j=1}^{n} \omega_{i j} x_{i}^{c} x_{j}^{c}
$$

\section{CNN 記憶容量調査シミュレーション}

次に, CNN の記憶容量について調査した。ニューロン数 $n(n=10,20, \cdots, 100)$ で構成したネットワークに 1～10 個の ランダムなパターンを記銘させ，記銘させたパターンに 20\%のノイズを含ませたパターンを初期状態として与えて ネットワークを動作させた。100 エピソード繰り返し，その 間に記銘パターンを正確に想起できたパターン数を想起パ ターン数とした。これを 1 試行としてこれを 1000 回試行し,

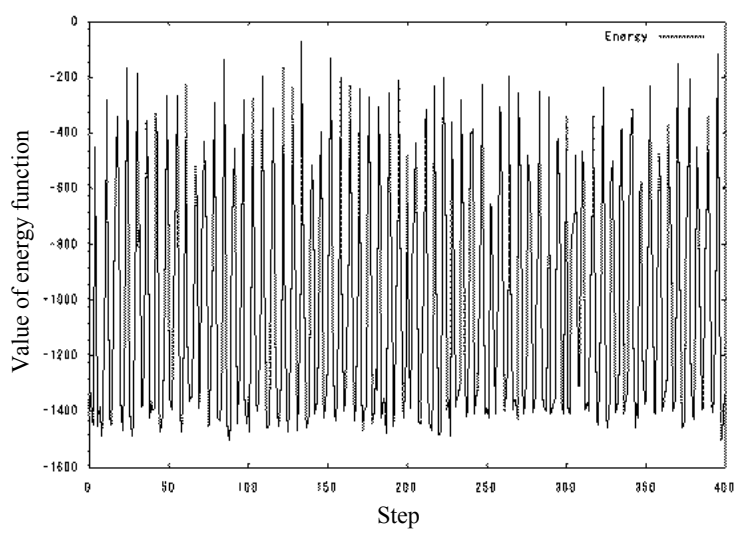

Fig. 4. Change of values of energy function in case of CNN

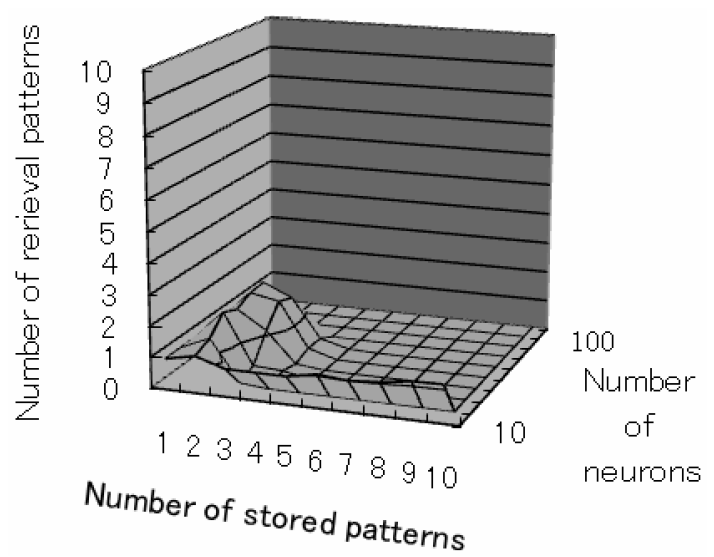

Fig. 5. Retrieval ability of CNN

その想起パターン数の平均の変化を示したものを Fig.5 に示 す。いずれのニューロン数においても想起成功パターン数 は 2 を超えていない。シグモイド関数を活性化関数とする 従来の静的な自己想起型連想記憶モデルの最大記憶容量が 約 $0.15 \mathrm{~N}$ (N はニューロン数) に比較し，この想起成功率の 低さは，記銘パターンを正確に想起できた場合を想起成功 とする条件の厳しさとカオス的動作，及び偽記憶によるも のと考えられる。即ち，前者においては，状態遷移により 記銘パターンの近傍まで接近するもののカオス的動作によ り，遷移を続け，記銘パターンと一致することなく遠ざか ることによる。

\section{3. 提案ニューロンと過渡的カオス連想記憶モデル (TCAMM)}

前章で述べたように，カオスニューラルネットワークは カオス的遍歴機能により, 動的にパターン空間を探索し, 記銘パターンと類似のパターンを想起するが正確に想起せ ず，記銘パターンと一致した場合のみを想起成功とすると その記憶容量は Fig.5に示すとおり, かなり低いものとなる。 そこで, 記憶容量の改善を目的とし, 合原らのカオスニュー ロンと動径基底関数を組み合わせた新たなカオスニューロ ンを提案する。その提案ニューロンを( 7 )( 8 )式に示す。そ して, 提案ニューロンに対して, -1 か 1 までの連続な外部 


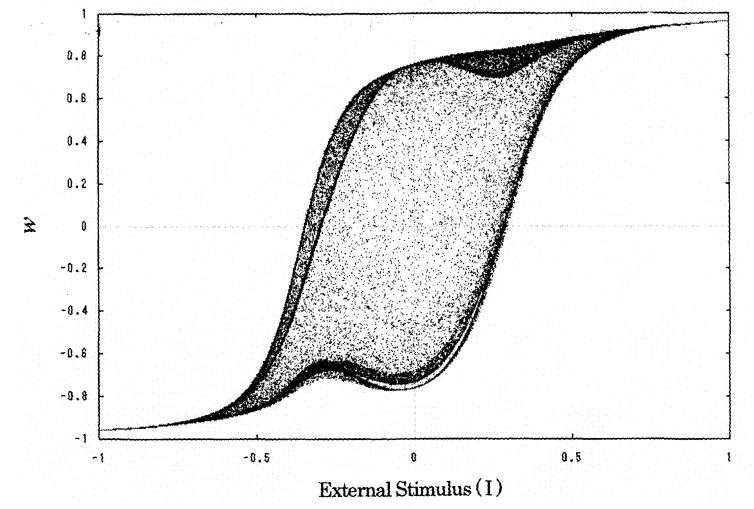

Fig. 6. Dynamics of the proposed neuron $\left(\left(\sigma^{2}=0.16\right)\right)$

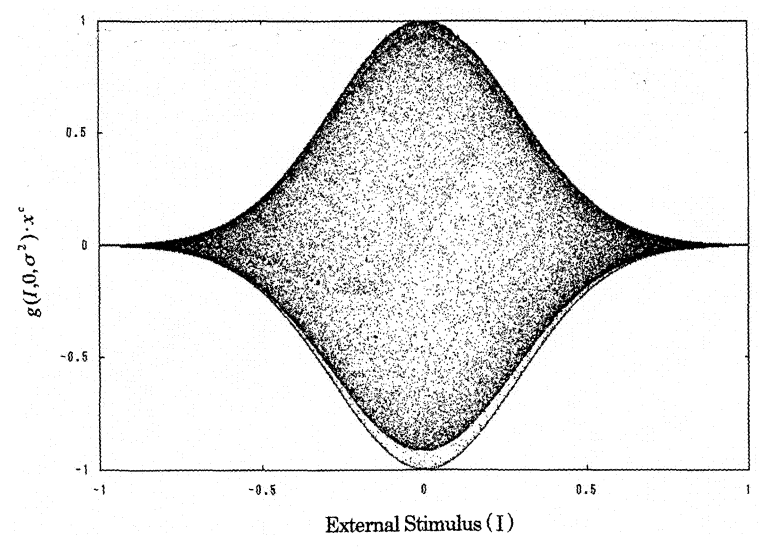

Fig. 7. Basic shape of chaotic field $\left(g\left(I, 0, \sigma^{2}\right) \cdot x^{c}(t)\right)$

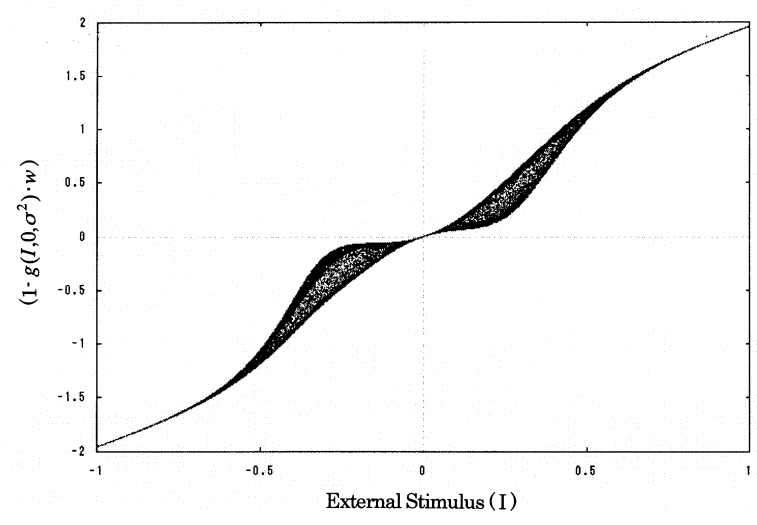

Fig. 8. Basic shape of neuron dynamics $\left(1-g\left(I, 0, \sigma^{2}\right) \cdot w(t)\right)$

入力に対する提案ニューロンの出力を Fig. 6 に示す。提案 ニューロンは限られた領域においてカオス状態を示してい ることが分かる。

$$
\begin{aligned}
& w(t+1)=f\left(g\left(I_{\text {out }}, \mu, \sigma^{2}\right) \cdot x^{c}\right. \\
& \left.+\left(1-g\left(I_{\text {out }}, \mu, \sigma^{2}\right)\right) \cdot w(t)+I_{\text {out }}(t)\right) \\
& g\left(x, \mu, \sigma^{2}\right)=e^{-\frac{(x-\mu)^{2}}{\sigma^{2}}}
\end{aligned}
$$

ここで $w(t)$ は時刻 $t$ における提案ニューロンの出力, $x^{c}(t)$ はカオスニューロンの出力 $((1) \sim(3)$ 式 $), f(\cdot)$ は活

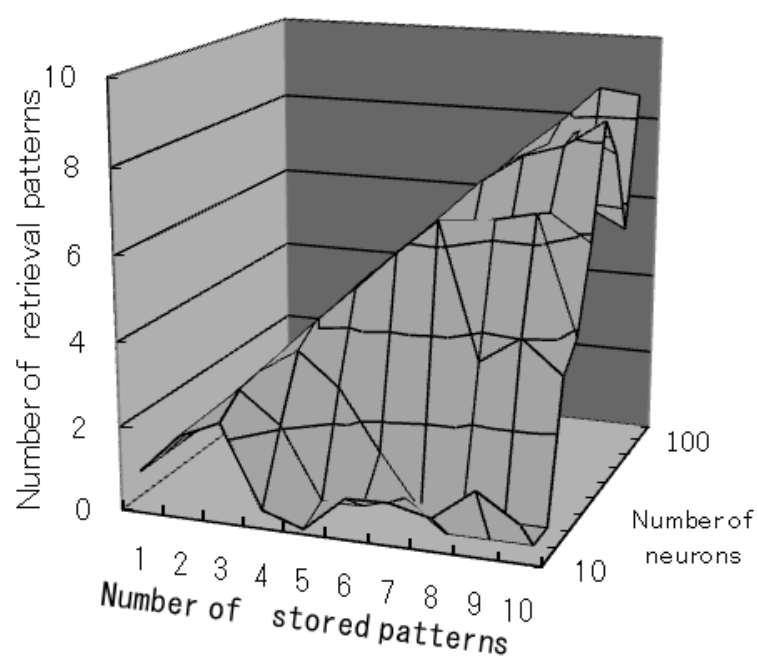

Fig. 9. Retrieval ability of TCAMM

性化関数 (( 4$)$ 式), $g\left(x, \mu, \sigma^{2}\right)$ は動径基底関数 (Radial Basis Function : RBF), $\mu$ は RBF の平均, $\sigma^{2}$ は RBF の分散 (Fig.7,8 参照), $I_{\text {out }}(t)$ は時刻 $t$ でのニューロンへの外部入力である。 提案するニューロンの出力波形 (Fig.6) は, その内部項で あるカオス領域を決定する項 $\left(g\left(I_{\text {out }}, \mu, \sigma^{2}\right) \cdot x^{c}(t) \quad\right.$ (Fig.7 参 照）と, 基本的な活性化関数のダイナミックスを決定する 項 $\left(1-g\left(I, \mu, \sigma^{2}\right) \cdot w(t)\right) \quad$ (Fig.8 参照) の二つのダイナミック スを統合したものと言える。

提案ニューロンとカオスニューロンダイナミックス （Fig.1）との違いはそのカオス領域の違いにある。カオス ニューロンのカオス領域はかなり広い。しかるに提案ニュー ロンのダイナミックスは合原らの提案したカオスニューロ ンダイナミックスを利用し, 動径基底関数を用いることで カオス発生領域に制限をかけており, その領域は動径基底 関数の分散で調整可能な制限された領域となっている。提 案するニューロンのダイナミックスでは, 他ニューロンか らの入力を含めた外部入力が小さい間はカオス的動作を, 外部入力が大きくなると通常の Hopfield の静的連想記憶モ デルのような収束動作を行うことを期待している（Fig.6 参 照)。本提案ニューロンを用いて Hopfield 型ネットワークを 構成し, 連想記憶能力を検証した。想起成功条件は 2 節の CNN のシミュレーションの場合と同様である。その結果を Fig.9 に示す。記憶容量が CNN (Fig.5) に比較し, 各段に向 上していることが分かる。

提案ニューロンはカオス領域が限定されていることか ら, 過渡的カオスの動作をし, その後, あるパターンへ収 束する。但し, 収束後, 再度, 他の記銘パターンへ $20 \%$ の ノイズを付加したパターンを初期パターンとして動作させ る。これを全てのパターンについて実施した。即ち, 提案 法である TCAMM を用いた場合, 数エピソードで記銘パ ターンもしくは偽記銘パターンへ収束するので, 収束した パターンについて記銘パターンとの一致・不一致で想起の 有無を判定しており（Fig.9）, 合原らの CNN の場合, 収束 
しないので 100 エピソードで打ち切り，100エピソード中で の記銘パターンの想起の有無を判定している（Fig.5）。

\section{4. 一時的滞留機能を持つ過渡的連想記憶モデル (TCAMMwithTSF)}

提案したニューロンダイナミックスは過渡的カオス動作 を行い，正確な記銘パターンを想起するものの収束してし まい, CNN のようなカオス的遍歴機能を持たない。そこで, この連想記憶モデルに動的なパターン空間探索能力（カオ ス的遍歴機能）を持たせるため，あるパターンに収束後， 不応状態になり, 一定時間経過後, 再度カオス状態に遷移 する能力, 即ち, 一時的滞留機能 (TSF) を付加する。

即ち, 提案ニューロンに合原らの提案したカオスニュー ロンにみられるような不応時間を与え, さらに外部入力值 を適宜縮小させ，状態をカオス領域へ変移させるための縮 小ニューロン（(9)式〜(15)式）を導入する。

$$
\begin{array}{ll}
I_{\text {out }}(t)=S_{\text {rate }} \cdot I(t) & \text { if } B(t-1)<0 \& B(t)>0 \\
S_{\text {rate }}=\beta & \quad \text { Otherwise. }
\end{array}
$$

$$
\begin{aligned}
& A(t)=\frac{4.0}{\max _{t}(I)+\min _{t}(I)} \ldots \ldots \ldots \ldots \ldots \ldots \ldots \ldots \ldots \\
& B(t)=k_{r} \cdot B(t-1)-\alpha \cdot x(\Delta I(t))+a
\end{aligned}
$$

$$
B(t)=B_{\max } \quad \text { if } \quad B(t)>B_{\max }
$$

$$
\Delta I(t)=|I(t)-I(t-1)|
$$

$$
x(\Delta I(t))=2 \quad \text { if } . \Delta I(t-1), \Delta I(t)=0 \& B(t-1)>0
$$$$
x(\Delta I(t))=0 \quad \text { Otherwise. }
$$

ここで， $S_{\text {rate }}$ は縮小率， $\beta$ は設定最高縮小率， $A(t)$ は縮 小率算出項, $B(t)$ は不応性に関する状態項, $B_{\text {max }}$ は不応性 項最大限界值， $x(t)$ はネットワーク収束判定項， $I(t)$ は外部 入力， $\alpha$ は定数パラメータ， $k_{r}$ は不応性に対する時間減衰 定数， $a$ は外部入力と閾值の複合項である。これら不応性 に関する項目は 2 節の CNN と同様である。( 6 )式の提案 ニューロンへの外部入力值は(9)式に示す縮小率の割合に 縮小される。

縮小の第一の目的は，外部入力值をほぼ-1〜1 の範囲に スケーリングさせることである。ここで，外部入力值をど れだけ縮小させるか，が問題となるが，外部入力值を必要 以上に縮小させると縮小された外部入力值のため，提案 ニューロンはカオスニューロンと同様な, カオス的なダイ ナミックスを出力する。この場合，合原らのカオスニュー ロンと同じく動的なパターン空間の探索は行えるが，ネッ トワークを一時的に収束させることは困難となる。また各 ニューロンに入力される外部入力值の大きさは TCAMM withTSF の構成ニューロン数, 記銘パターンにより決定され る結合重みにより変化するため, 各ニューロン個別に随時
適切な值を設定する必要がある。そこで縮少率を(11)式のよ うにした。過去最大の外部入力值と過去最小の外部入力值 を用いることで, どのような TCAMM withTSF にでもある 程度対応可能な縮小率を設定することができる。

また(10)式に示すように, 縮小率は不応性に関する状態項 $B(t)$ により変化する。 $B(t)$ は提案ニューロンの不応性を制 御する項であり， $B(t)$ が負数の場合，不応状態を示す。ま た, ネットワーク収束判定項 $x(\Delta I(t))$ は, 外部入力の前時刻 との差分が $0(\Delta I(t-1)=\Delta I(t))=0)$ の場合かつ縮小二ュー ロンが活性時のみ值を持つ。ここで，HN の特性よりネット ワークが記銘パターン想起に向かって遷移している場合は 外部入力が変化し, ネットワークが安定状態になったとき 変化がなくなることを考慮すると, $B(t)$ はネットワークが 安定状態に移行した, つまり何らかのパターンを想起した 場合のみ負数をとり, それ以外の場合は正数をとることに なる。そして，ニューロンが更新されるたびに $B(t)$ に $a$ が 加算される。このようにして更新を重ね， $B(t)$ が正数にな るまでの間, 提案ニューロンは不応状態となる。

設定最高縮小率 $\beta$ はきわめて小さな值を設定しておく必 要がある。これは不応状態より復帰したとき, 提案ニュー ロンを再度カオス状態にするためである。不忘状態から抜 け出したニューロンは一定時間, 極度に縮小させられた外 部入力を受け取ることでカオス状態に遷移し, 再度動的な パターン空間探索を行う。このような機能を持つ縮小ニュー

\begin{tabular}{|c|c|c|}
\hline \multicolumn{2}{|l|}{ parameter } & value \\
\hline \multicolumn{3}{|l|}{ parameters on neuron dynamics } \\
\hline slope parameter of sigmoid function & $\varepsilon$ & 5.0 \\
\hline mean of RBF & $\mu$ & 0.0 \\
\hline variance of RBF & $\sigma^{2}$ & 0.01 \\
\hline scaling parameter for internal state & $\alpha$ & 10.0 \\
\hline decay parameter for internal state & $k_{r}$ & 0.99 \\
\hline decay parameter for mutual interaction state & $k_{f}$ & 0.3 \\
\hline composite term of external input and threshold & $a$ & 3.0 \\
\hline \multicolumn{3}{|l|}{ parameters on reduced neuron } \\
\hline initial value of term calculating reduction ratio & $A(0)$ & 1.0 \\
\hline initial value of refractory state & $B(0)$ & 0.0 \\
\hline maximal reduction ratio & $\beta$ & 0.001 \\
\hline scaling parameter for refractory state & $\alpha$ & 10.0 \\
\hline maximal value of refractory state & $B_{\max }$ & 12.0 \\
\hline decay parameter for refractory state & $k_{r}$ & 0.99 \\
\hline composite term of external input and threshold & $a$ & 3.0 \\
\hline
\end{tabular}
ロンを導入することにより，提案ニューロンは収束性をも ちつつ, 一定時間経過後, 合原らの提案したカオスニュー ロンのようなカオス的遍歴を行うことが可能となる。Table 2 に検証に用いたパラメータを示す。縮小ニューロン関連は 不応答状態が最低 4 ステップは保たれるように設定してい る。

Table 2. Parameters for experiment 
ところで, TCAMMwithTSF では，TCAMM における一時 的な収束状態から, 縮小ニューロンの導入により, 外部入 力を縮小させたが, 逆に, Fig.6において, RBF の広がり $(\sigma)$

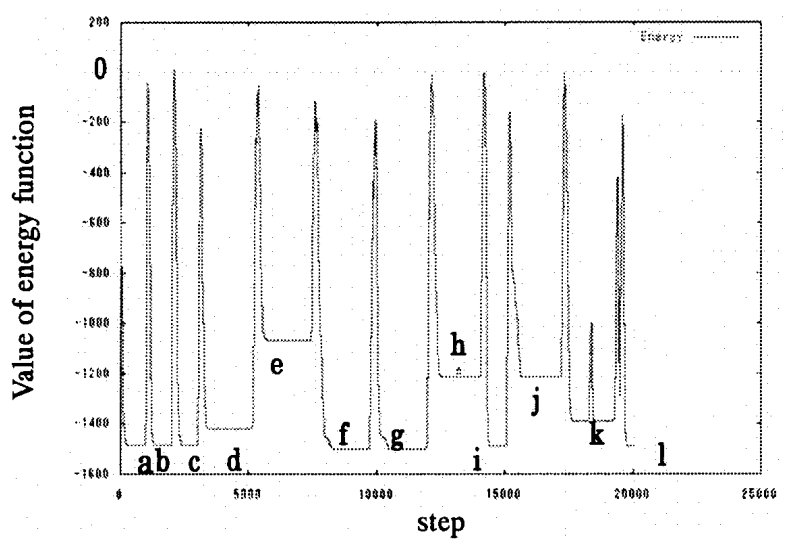

Fig. 10. Values of energy function of TCAMMwithTSF

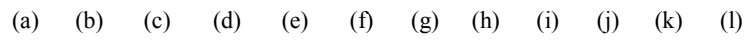

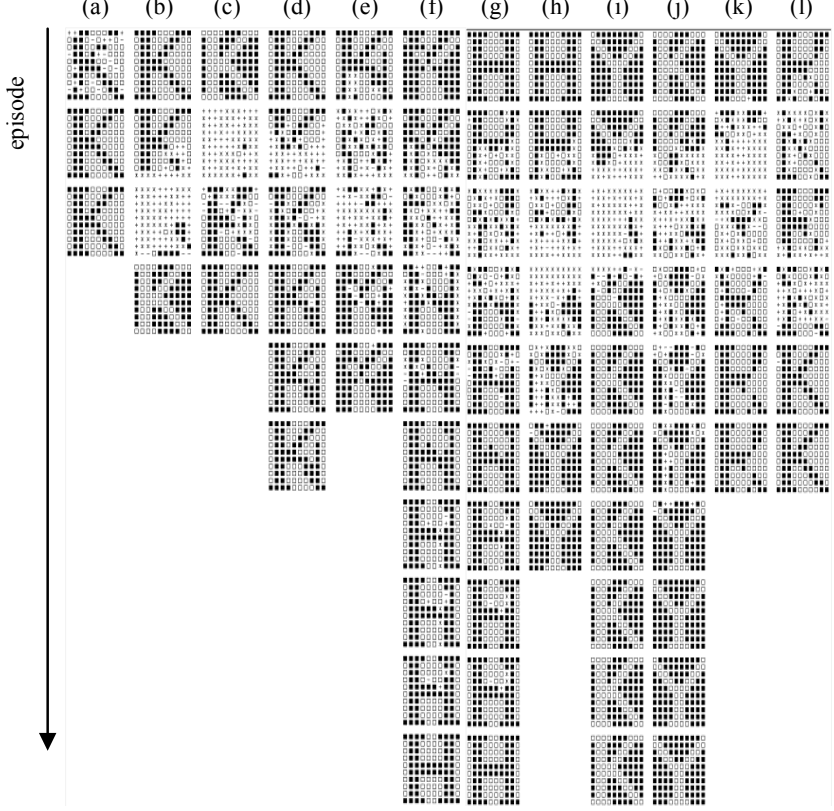

Fig. 11. States transmission of TCAMMwithTSF

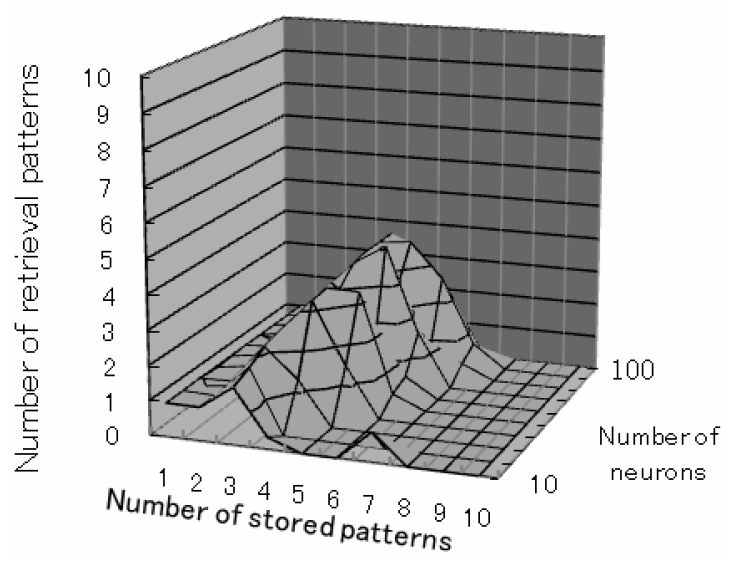

Fig. 12. Retrieval ability of TCAMMwithTSF
を変化させることで，提案法と同様な目的を実現させるこ とも考えられる。しかしながら, 本提案では, パラメータ を人為的に変化させるのではなく, あくまでも内部状態の 変化でカオス的遍歴の実現を目的としているため, RBF の $\sigma$ は固定とし，のによる調整は行わない。

\section{5. 計算機シミュレーション}

〈5・1〉 TCAMM with TSF としての動作 提案ニュー ロンを用いて TCAMMwithTSF を構成する。シミュレーショ ンで使用したパラメータを Table 2 に示す。これらは試行錯 誤にて設定し, 結果的に記憶容量が最大となったものを表 記している。TCAMMwithTSF を構成するにあたり，ニュー ロンへの外部入力 $I(t) （(9)$ 式）を(16)式のように修正する。

$$
I_{i}(t)=\sum_{j=1}^{N} \omega_{i j} w_{j}(t)
$$

ここで， $I_{i}(t)$ は TCAMMwithTSF を構成する $i$ 番目ニュー ロンへの外部入力, $\omega_{i j}$ は $i$ 番目ニューロンと $j$ 番目ニュー ロン間の結合重み $\left((5)\right.$ 式参照),$w_{j}(t)$ は $j$ 番目ニューロン の出力值である。この TCAMMwithTSF に4つのパターンを 記銘して想起させた (Fig.2 参照)。このときのエネルギー関 数の遷移（Fig.10）において, 所々にあるエネルギー関数值 が一定期間継続している箇所が，TCAMMwithTSF が記銘パ ターンまたは偽記銘パターンに一時的に収束している箇所 である。Fig.11 には Fig.10のエネルギー関数值が一定期間継 続しているとき $(a, b, \cdots, 1)$ のネットワークの想起パターンを 示す。これらより, 提案ニューロンで構成された連想記憶 モデルは CNN の正確とは言えない想起状態 (Fig.3) と違い, Fig.4のような動的なパターン空間の探索を進めつつ, 多く の場合で正確な記銘パターンへ一時的に収束し, その後力 オス的探索を行っていることがわかる。

〈5·2〉 記憶容量 次に TCAMMwithTSF の記憶容量 の調查を行った。方法は 2 節のカオスニューラルネットワー クの記憶容量調査と同様である。その結果を Fig.12 に示す。 合原らの CNNを用いた連想記憶モデルの容量より増加して いることが分かる (Fig.5 参照)。提案モデルはあるパターン を想起後, 一定期間想起状態を保持し, その後, カ才ス的 遷移により，更に記銘パターンを探索するという意味では $\mathrm{CNN}$ と同じ想起条件と言える。即ち, 提案法は, ある記銘 パターンにノイズを付加した初期パターンから探索を開始 し, あるパターンを想起した状態を一定時間継続し, その 後, カオス的探索を続けるという当初の目的を達し, かつ, その記憶容量もカオス的遍歴機能を持つ CNN の記憶容量を 超えている。

\section{6. まとめ}

本論文では，合原らの提案したカオスニューロンと動径 基底関数 (RBF) を組み合わせたニューロンを提案し, 提案 ニューロンを用いて, 過渡的カオス状態を経由し, より正 確な記銘パターンへ収束する連想記憶モデル（TCAMM）の 提案を行った。さらに, 提案ニューロンに新たに外部入力 
值の縮小機能を導入することにより，従来のカオスニュー ロンにはできなかった記銘パターン（偽記銘パターンを含 む）での一定時間の滞留とその後のカオス的遍歴を実現し た (TCAMMwithTSF)。

しかしながら, 今回提案の方法では, 過度的カオス連想 記憶（TCAMM）による記憶能力はある程度改善されている が, 縮小ニューロンを追加した TCAMMwithTSF では記憶能 力が低下している。さらに, 縮小ニューロンは, 設定す心゙ きパラメータも多く, 式も複雑である。今後の課題として, 記憶能力低下の要因である縮小ニューロンの構成方法の工 夫による記憶能力の改善がある。さらには，実用的な応用， 例えば，目視による特定の顔画像のディスプレイ上での認 識など, を考慮すれば, 2 值での取り扱いから多值への拡張， 記憶容量の実用レベルへの拡大が挙げられる。

(平成 20 年 3 月 19 日受付, 平成 20 年 7 月 19 日再受付)

\section{文献}

(1) C. A. Skarda and W. J. Freeman : "How brains makes chaos in order to make sense of the world", Behavioral and Brain sciences, Vol.10, pp.161-195 (1987)

(2) A. Babloyants and J. M. Salazar : "Evidence of chaotic dynamics of brain activity during the sleep cycle", Physics Letters A, Vol.111, pp.152-156 (1985)

( 3 ) K. Aihara, G. Matsumoto, and M. Ichikawa : "An alternating periodic-chaotic sequence observed in neural Oscillations", Physics Letters A, Vol.111, No.5, pp.251-255 (1985)

(4) K. Aihara, T. Tanabe, and M. Toyoda : "Chaotic Neural Networks", Physics Letters A, Vol.144, pp.333-340 (1990)

(5) J. J. Hopfield : "Neurons with graded response have collective computational properties like those of two-state neurons", Proceedings of the National Academy of Sciences U.S.A, Vol.81, pp.3088-3092 (1984)

(6) M. Adachi and K. Aihara : "Associative Dynamics in Chaotic Neural Network", Neural Networks, Vol.10, pp.83-98 (1997)

(7) Raymond S. T. Lee : "A Transient-chaotic Auto-associative Network (TCAN) Based on Lee Oscillators", IEEE Trans. on Neural Networks, Vol.15, No.5, pp.1228-1243 (2004)

(8) K.Aihara : "Chaos Seminar", Chapter.7, Kaibundo (1994) (in Japanese) 合原一幸編：「カオスセミナー」，7 章，海文堂 (1994)
大 林 正 直 (正員) 1975 年 3 月九州工業大学工学部電気工

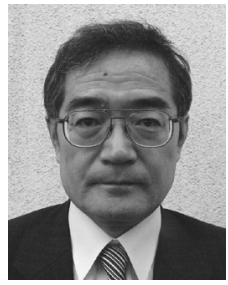
学科卒業。1977 年 3 月九州大学大学院工学研究 科修士課程電気工学専攻修了。1977 年 4 月 (株) 日立製作所入社大夕か工場勤務。1989 年 4 月九 州大学工学部助手。1 1997 年 7 月同助教授。1 1998 年 4 月山口大学工学部助教授 2001 年 7 月同教 授。2006 年 4 月同大学院理工学研究科教授。現 在に至る。計測自動制御学会, 日本知能情報フ アジィ学会, 日本ロボット学会, 人工知能学会, 米国電気電子学会 の各会員。博士 (工学)。

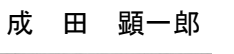

（非会員） 2004 年 3 月山口大学工学部知能情報 システム工学科卒業。2006 年 3 月山口大学大学 院理工学研究科博士前期課程知能情報システ 厶工学専攻修了。2006 年 4 月富士通 (株) 入社。 現在に至る。

小 林 邦 和 (非会員) 1991 年 3 月山口大学工学部電子工学

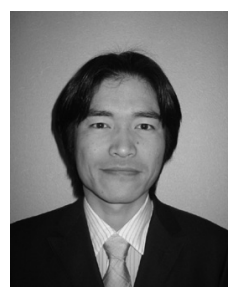
科卒業。1993 年 3 月同大大学院工学研究科博士 前期課程知能情報システム工学専攻修了。1994 年 3 月同大大学院工学研究科博士後期課程シス テム工学専攻退学。1994 年 4 月同大工学部知能 情報システム工学科助手。2007 年 4 月同大学院 理工学研究科助教。現在に至る。米国電気電子 学会, 電子情報通信学会, 日本神経回路網学会 の各会員。

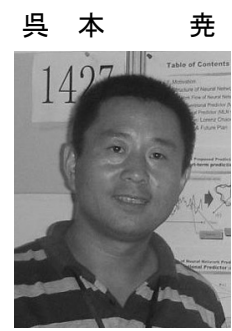

（非会員） 1986 年 7 月中国上海機械学院大学 (現：上海理工大学) システム工学科卒業。1986 年 8 月中国機械工業部 (省) 北京機械工業自動 化研究所。1996 年 3 月山口大学大学院理工学 研究科博士前期課程知能情報システム工学専 攻修了。1997 年 3 月同大大学院理工学研究科 博士後期課程システム工学専攻退学。1997 年 4 月同大工学部知能情報システム工学科教務員。 2005 年 4 月同助手。 2007 年 4 月同大学院理工学研究科助教。現在 に至る。電子情報通信学会会員, 米国電気電子学会の各会員。 